\title{
Correction to: Experimental tail shortening affects feeding rate depending on original tail length in female barn swallows Hirundo rustica gutturalis
}

\author{
Masaru Hasegawa ${ }^{1}$. Emi Arai ${ }^{1} \cdot$ Masahiko Nakamura $^{2}$
}

Published online: 31 December 2020

(C) Japan Ethological Society 2020

\section{Correction to: Journal of Ethology (2020) 38:179-184 https://doi.org/10.1007/s10164-019-00637-y}

The article Experimental tail shortening affects feeding rate depending on original tail length in female barn swallows Hirundo rustica gutturalis, written by Masaru Hasegawa, Emi Arai, Masahiko Nakamura, was originally published Online First without Open Access. After publication in volume 38 , issue 2, page 179-184 the author decided to opt for Open Choice and to make the article an Open Access publication. Therefore, the copyright of the article has been changed to (C) The Author(s) 2020 and the article is forthwith distributed under the terms of the Creative Commons Attribution 4.0 International License, which permits use, sharing, adaptation, distribution and reproduction in any medium or format, as long as you give appropriate credit to the original author(s) and the source, provide a link to the Creative Commons licence, and indicate if changes were made. The images or other third party material in this article are included in the article's Creative Commons licence, unless indicated otherwise in a credit line to the material. If material is not included in the article's Creative Commons licence and your intended use is not permitted by statutory regulation or exceeds the permitted use, you will need to obtain permission directly from the copyright holder. To view a copy of this licence, visit http://creativecommons .org/licenses/by/4.0/.

The original article has been corrected.

Open Access This article is licensed under a Creative Commons Attribution 4.0 International License, which permits use, sharing, adaptation, distribution and reproduction in any medium or format, as long as you give appropriate credit to the original author(s) and the source, provide a link to the Creative Commons licence, and indicate if changes were made. The images or other third party material in this article are included in the article's Creative Commons licence, unless indicated otherwise in a credit line to the material. If material is not included in the article's Creative Commons licence and your intended use is not permitted by statutory regulation or exceeds the permitted use, you will need to obtain permission directly from the copyright holder. To view a copy of this licence, visit http://creativecommons.org/licenses/by/4.0/.

Publisher's Note Springer Nature remains neutral with regard to jurisdictional claims in published maps and institutional affiliations.

The original article can be found online at https://doi.org/10.1007/ s10164-019-00637-y.

Masaru Hasegawa

perorobomusadiobe@gmail.com

1 Department of Evolutionary Studies of Biosystems, Sokendai (The Graduate University for Advanced Studies), 1560-35 Kamiyamaguchi, Hayama-machi, Miura, Kanagawa 240-0115, Japan

2 Laboratory of Animal Ecology, Department of Biology, Joetsu University of Education, 1 Yamayashiki-machi, Joetsu-shi, Niigata 943-8512, Japan 